\title{
Effect of Self-Efficacy on Job satisfaction and Resilience in Urban Health Professionals
}

\author{
Bijal Kampani ${ }^{1}$ \\ ${ }^{1}$ Post Graduate Student, Department of Psychology, Smt. Maniben Nanavati Women's College, \\ Mumbai \\ E-mail - bijalokampani@gmail.com
}

\begin{abstract}
The study of job satisfaction and resilience have been done in the past a number of times but very little research has been conducted on more than one health discipline and no research was identified that combined more than one health disciplines considered in this review. The aim of this systematic review is to study the effect of self efficacy on General health and Mental health professionals and thereby understanding the impact of job satisfaction and resilience on health professionals. One hundred Health Professionals from the region of Mumbai were selected as participants. Data was gathered through a survey, featuring three questionnaires measuring the three variables of interest: Resilience, Job satisfaction and Self efficacy. There is a difference in the job satisfaction of Mental Health Professionals and General Health Professionals, there is a difference in the job satisfaction of High self efficacy and Low self efficacy Professionals and the mental health Professionals with High self efficacy have highest job satisfaction. Resilience and Job satisfaction play a vital role in the self efficacy of the health professionals however very little is known about the effect of one on another.
\end{abstract}

Key words: Job Satisfaction, Self efficacy, Resilience, Mental health Professionals, General health professionals.

\section{INTRODUCTION}

Today's economic environment has placed increasing pressure on humans to accomplish more within exciting and sometimes even reduced resources. The pressure to accomplish more with essentially the same or sometimes even less resources represents a significant challenge to management. It is believed that in the process of accepting these challenges ones mental and physical state might get affected, ranging from serious health issues. Thus, in order to be taken care, there is a need for health professionals. The purpose of this study is to study the effect of self efficacy on job satisfaction and resilience in health professionals.

A mental health professional is a health care practitioner who offers services for the purpose of improving an individual's mental health or to treat mental illness. This broad category includes psychiatrists, psychiatric nurses, clinical psychologists, clinical social workers, mental health counselors, professional counsellors, as well as many other professionals. These professionals often deal with the same illnesses, disorders, conditions and issues however their scope of practice differs [1]. The 
most significant difference between mental health professionals are the laws regarding education and training across various professions.

A general health professional is the one who takes care of terminally ill patients as well as various type of surgery and disorders as well. The kind of professionals who fall under the umbrella of General health Professionals are the doctors, nurses, ward boys, surgeons etc. These professionals generally deal with the direct physiological conditions that are causing trouble to the patients. They do not enter the circle of the psyche/mind. Direct treatment over the problem is their goal and most of the times there is a lot of medicine prescription used as compared to any therapy.

Job satisfaction is how content an individual is with his or her job. Scholars and human resource professionals generally make a distinction between affective job satisfaction and cognitive job satisfaction [2]. Affective job satisfaction is the extent of pleasurable emotional feelings individuals have about their jobs overall, and is different to cognitive job satisfaction which is the extent of individuals' satisfaction with particular facets of their jobs, such as pay, pension arrangements, working hours, and numerous other aspects of their jobs.

Resilience is an individuals tendency to cope with stress and adversity. This coping may result in the individual "bouncing back" to a previous state of normal functioning, or simply not showing negative effects. Resilience is most commonly understood as a process, and not a trait of an individual [3]. Self-efficacy is the extent or strength of one's belief in one's own ability to complete tasks and reach goals. Psychologists have studied self-efficacy from several perspectives, noting various paths in the development of self-efficacy; the dynamics of self-efficacy, and lack thereof, in many different settings; interactions between self-efficacy and self-concept; and habits of attribution that contribute to, or detract from, self-efficacy [4].

\section{METHODOLOGY}

This study can be considered a 2(Health Professional and Self efficacy) $X 2$ (resilience and job satisfaction) between subject factorial design because there are two independent variables with two levels each. One hundred Health Professionals from the region of Mumbai were selected as participants. The health professionals were specifically targeted from Mental Health and General Health Professions. They fall in the age ranging from 35 to 60 years. In terms of General Health Professionals, only Doctors and nurses were included for data collection. In the same manner for Mental Health Professional, a data from Psychiatrist and School/ Vocational Counsellors/Remedial Teachers was only targeted. In terms of gender, it was distributed between male and female unequally. Informed consent was obtained from the professionals. Inclusions used for the research are: firstly, participants should be in the age group of 35 to 60 years. Secondly, the participants must have a certified degree of their profession. And lastly, the participants must be English speaking, writing and reading. Exclusions used for this research are: firstly, anyone who is 35 years below and 60 years above of age should not be a participant. Secondly, any person suffering from a grave physical or mental illness are excluded from participation. Thirdly, anyone who is in the process of gaining a degree or does not officially have a degree into his/ her respective field are excluded. And lastly, anyone who is not familiar with reading, writing and speaking English language are excluded from this research.

The informed consent was taken from the participants. Participants were told about the general nature of the study and it was ensured that confidentiality will be maintained throughout the research. Participants were not forced 
to fill up the questionnaire and were given a freedom of choice. Three scales are used for the data collection. The first scale is for measuring job satisfaction and is called as the Job Satisfaction Survey Scale. Psychometric properties of the scale: Internal reliability estimates for each subscale of the 1997 Job Satisfaction Scale were calculated from the approximately 1600 cases of the national norm data [5]. Coefficient alpha estimates of reliability. The second scale which is used to measure resilience is the Connor Davidson Resilience Scale. The author's permission was obtained and only then the scale was used for research. Concurrent (convergent) validity was calculated by showing that the scale correlates with like measures, either of resilience itself or related measures such as depression, stress coping, self-esteem, optimism etc. Three Chinese studies have assessed the convergent validity of the CD-RISC. In one study [6], the CDRISC correlated with the Rosenberg Self-Esteem Scale $(r=0.49, p<0.01)$, the Life Satisfaction Index $A(r=0.48, p<0.01)$, and all five factors if the NEO-FFI (i.e. neuroticism, $r=-0.47$; extraversion, $r=0.43$; openness, $r=0.27$; agreeableness, $r=0.36$; conscientiousness, $r=0.64-$ all $p<001$ ).

The third scale which is used to measure self efficacy is the general efficacy scale (GSE). This scale is available on the public domain hence permission from the author was not required. Several researchers [7-8] have suggested that SSE is a motivational state and GSE is a motivational trait. Internal consistency reliability for the SGSE scale in organizational research hasbeen moderate to high ( $a=$ .76 to .89) [9-11]. Using the Hebrew version of the SGSE scale, Eden and colleagues [12-14] have obtained similar coefficient alphas in Israeli samples. However, the only study that reported the SGSE scale's test-retest reliability [15] yielded a low estimate $(r=.23)$ across only 3 weeks. Thus, although the SGSE scale has been found to be internally consistent in numerous organizational studies, the little known about its testretest reliability is not encouraging. However, only one study has examined this issue. Establishing the stability of any GSE measure is crucial, given that GSE has been conceptualized as a stable, trait-like construct.

Data was gathered through a survey, featuring three questionnaires measuring the three variables of interest: Resilience, Job satisfaction and Self efficacy among 100 health professionals. The participants were told that they will be given the results and the purpose of the study if they want to have a look at it only after the entire research is completed. The two independent variables involves two levels: Self Efficacy (High and Low) and health professionals (Mental Health and General Health) however the two dependent variables i.e. Job satisfaction and Resilience are on interval scale hence to assess the difference, MANOVA (Multi variate Analysis of Variance) is done to check if there is any statistical significance for both the dependent variables.

\section{RESULTS}

A total sample $(\mathrm{N}=100)$ was composed of male and female health professionals. A total of 50 general health professionals and 50 mental health professionals were being surveyed for the study. Participants age ranged from 35 to 60 years, hence the mean age was 47.5 years. The means and standard deviations of Job satisfaction are presented in Table 1a. As per the table, the mean of General health professional with Low Self Efficacy is 59.85 and Standard Deviation is 11.32. In the same way mean of General Health Professional with High self efficacy is 74.00 and the Standard Deviation is 18.75. The mean of Mental Health professional with Low self efficacy in Job satisfaction is 69.26 and the standard deviation obtained is 17.41 and 
those with High self efficacy have a mean of 80.04 and a standard deviation of 8.57. The means and standard deviations of Resilience are presented in Table 1b. As per the table, the mean of General health professional with Low Self Efficacy is 112.90 and Standard Deviation is 22.03. In the same way mean of General Health Professional with High self efficacy is 112.53 and the Standard Deviation is 23.71. The mean of Mental Health professional with Low self efficacy in Resilience is 109.15 and the standard deviation obtained is 21.56 and those with High self efficacy have a mean of 111.79 and a standard deviation of 22.28 .

Table 1a - Descriptive statistics for Job Satisfaction

\begin{tabular}{|c|c|c|c|c|c|}
\hline Variable & $\begin{array}{l}\text { Health } \\
\text { Professional }\end{array}$ & Self Efficacy & Mean & $\begin{array}{l}\text { Standard } \\
\text { Deviation }\end{array}$ & $\mathrm{N}$ \\
\hline $\begin{array}{l}\text { Job } \\
\text { Satisfaction }\end{array}$ & $\begin{array}{l}\text { General H.P } \\
\text { Mental H.P } \\
\text { Total }\end{array}$ & $\begin{array}{l}\text { Low S. E } \\
\text { High S.E } \\
\text { Total } \\
\text { Low S.E } \\
\text { High S.E } \\
\text { Total } \\
\text { Low S.E } \\
\text { High S.E } \\
\text { Total }\end{array}$ & $\begin{array}{l}59.85 \\
74.00 \\
68.34 \\
69.26 \\
80.04 \\
74.44 \\
65.17 \\
76.68 \\
71.39\end{array}$ & $\begin{array}{l}11.32 \\
18.57 \\
17.40 \\
17.41 \\
8.57 \\
14.79 \\
15.65 \\
15.16 \\
16.36\end{array}$ & $\begin{array}{l}20 \\
30 \\
50 \\
26 \\
24 \\
50 \\
46 \\
54 \\
100\end{array}$ \\
\hline
\end{tabular}

Table 1b - Descriptive statistics for Resilience

\begin{tabular}{|c|c|c|c|c|c|}
\hline Variable & $\begin{array}{l}\text { Health } \\
\text { Professional }\end{array}$ & Self Efficacy & Mean & $\begin{array}{l}\text { Standard } \\
\text { Deviation }\end{array}$ & $\mathrm{n}$ \\
\hline Resilience & $\begin{array}{l}\text { General H.P } \\
\text { Mental H.P } \\
\text { Total }\end{array}$ & $\begin{array}{l}\text { Low S.E } \\
\text { High S.E } \\
\text { Total } \\
\text { Low S.E } \\
\text { High S.E } \\
\text { Total } \\
\text { Low S.E } \\
\text { High S.E } \\
\text { Total }\end{array}$ & $\begin{array}{l}112.90 \\
112.53 \\
112.68 \\
109.15 \\
111.79 \\
110.42 \\
110.78 \\
112.20 \\
111.55\end{array}$ & $\begin{array}{l}22.03 \\
23.71 \\
22.82 \\
21.56 \\
22.28 \\
21.72 \\
21.60 \\
22.87 \\
22.20\end{array}$ & $\begin{array}{c}20 \\
30 \\
50 \\
26 \\
24 \\
50 \\
46 \\
54 \\
100\end{array}$ \\
\hline
\end{tabular}

As per the given table, we can interpret that there is a significant effect of Health Professionals, Wilks' Lambda $=.91, F(2,95)=4.25, p=.017$. However there is no effect on self efficacy, Wilks' Lambda $=8.40, F(2,95)=9.06, p=2.00$ Lastly, the table also interprets the interaction of the two independent variables

i.e. Health professionals and Self efficacy and the results illustrate that there is an effect on the two tos Wilks' Lambda $=0.99, \mathrm{~F}(2,95)=0.30, \mathrm{p}=0.06$

Table 3 below 


\begin{tabular}{|l|l|l|l|l|}
\hline Effect & & Value & F & Significance \\
\hline $\begin{array}{l}\text { Health } \\
\text { Professionals } \\
\text { Self efficacy }\end{array}$ & $\begin{array}{l}\text { Wilks' } \\
\text { Lambda } \\
\text { Wilks' } \\
\text { Lambda }\end{array}$ & 8.91 & $4.251 \mathrm{~b}$ & .017 \\
$\begin{array}{l}\text { Health } \\
\begin{array}{l}\text { Professional } \\
\text { S.efficacy }\end{array}\end{array}$ & $\begin{array}{l}\text { Wilks' } \\
\text { Lambda }\end{array}$ & 9.06 & 2.00 \\
& .99 & 0.30 & 0.006 \\
\hline
\end{tabular}

Table 4

\begin{tabular}{|c|c|c|c|c|c|c|}
\hline & & Sum of Squares & $\mathrm{df}$ & Mean Square & $\mathrm{F}$ & Sig. \\
\hline \multirow{2}{*}{$\begin{array}{l}\text { Health } \\
\text { Professionals }\end{array}$} & JS & 1462.35 & 1 & 1462.35 & 6.46 & .01 \\
\hline & RES & 123.21 & 1 & 123.21 & .24 & .62 \\
\hline \multirow[t]{2}{*}{ Self Efficacy } & JS & 3799.84 & 1 & 3799.84 & 16.79 & .00 \\
\hline & RES & 31.55 & 1 & 31.55 & .06 & .80 \\
\hline \multirow[t]{2}{*}{ H.Prof * ses } & JS & 69.79 & 1 & 69.79 & .30 & .58 \\
\hline & RES & 55.22 & 1 & 55.22 & .10 & .74 \\
\hline \multirow[t]{2}{*}{ Error } & JS & 21716.62 & 96 & 226.21 & & \\
\hline & RES & 48578.61 & 96 & 506.02 & & \\
\hline \multirow[t]{2}{*}{ Total } & JS & 536151.00 & 100 & & & \\
\hline & RES & 1293135.00 & 100 & & & \\
\hline
\end{tabular}


We can follow up these significant MANOVAs with pair wise comparison for Job satisfaction and Resilience in table 4 . Table 4 reports the mean scores for high and low Self efficacy for job satisfaction and resilience. The mean scores for Job satisfaction with its comparison to Low to High self efficacy is statistically significant, $(p<.005$, as $p=0.00)$. Mean scores for Job satisfaction with its effect on High Self Efficacy and Low self efficacy is statistically significant, $(p<.005$, as $p=0.001)$. The mean scores for resilience for Low and high Self efficacy is not statistically significant, $p<0.005$ as $p<0.751$. Mean scores for Resilience with effect to High self efficacy and Low self efficacy is not statistically significant, $p<0.005$, as $p=$ 0.75 .

Table 5 -Pair wise Comparison of IV and DV.

\begin{tabular}{|c|c|c|c|c|c|}
\hline \multicolumn{3}{|c|}{$\begin{array}{l}\text { Dependent } \\
\text { Variable }\end{array}$} & $\begin{array}{l}\text { Mean } \\
\text { Difference } \\
(\mathrm{I}-\mathrm{J})\end{array}$ & Std. Error & Sig. ${ }^{b}$ \\
\hline \multirow[t]{2}{*}{ JS } & $\begin{array}{l}\text { Low } \\
S F\end{array}$ & $\begin{array}{l}\text { High } \\
\text { SF }\end{array}$ & $-11.511^{*}$ & 3.088 & .000 \\
\hline & $\begin{array}{l}\text { High } \\
\text { S.E }\end{array}$ & $\begin{array}{l}\text { Low } \\
\text { S.E }\end{array}$ & $11.511^{*}$ & 3.088 & .000 \\
\hline \multirow[t]{2}{*}{ RES } & $\begin{array}{l}\text { Low } \\
\text { S.E }\end{array}$ & $\begin{array}{l}\text { High } \\
\text { S.E }\end{array}$ & -1.421 & 4.475 & .751 \\
\hline & $\begin{array}{l}\text { High } \\
\text { S.E }\end{array}$ & $\begin{array}{l}\text { Low } \\
\text { S.E }\end{array}$ & 1.421 & 4.475 & .751 \\
\hline
\end{tabular}

\section{DISCUSSION}

Resilience is a multidimensional concept and might be affected by other factors such as biological, demographic, or contextual factors. Future research could search for biological, demographic or contextual markers that can increase or decrease resilience. The most significant limitation was the instruments. As self-report instruments these instruments may have imposed limitations on the findings due to common problems such as response bias, accuracy of recall, interpretation of scenarios and descriptors. Another limitation could be that participants were drawn from a sample of Mumbai region of the country. People from other region of the country may differ. Size of the population is also one of the significant limitations here. The sub field chosen of Mental Health professionals can be one of the limitations too. Finally, there can be a problem of self-selection or volunteer bias. It is possible that the people who chose to participate in this study varied from the people that did not choose to participate. The difference in the people who did not participate may have added a different dimension to the variance, therefore altering the results.

This study suggests the effect of high self efficacy on job satisfaction specifically in Mental Health Professionals. Even in terms of professions, there seems to be greater resilience and job satisfaction in mental health professionals as compared to general health professionals. Thus this research gives one constant outcome about 
more job satisfaction and resilience in mental health professionals as compared to general health professional. This research finding can be therefore used to understand the differences in both these discipline and what makes mental health professional more satisfied with their jobs too. A detailed analysis and survey can be carried out to find the differences between these two same yet different professions and the results obtained can benefit in increasing the job satisfaction and resilience in general health professionals as well. Theoretically, this study has provided support for the continued study of the direct effect of self efficacy on the relationship between resilience and job satisfaction in health professionals.

\section{REFERENCES}

1. Wolin SJ, Wolin S. The resilient self: How survivors of troubled families rise above adversity. New York: Villard Books ; 1993.

2. Stoltz, P. Adversity Quotient: Turning obstacles into opportunities. New York: John Wiley \& Sons ; 1997.

3. Maston, A. Resilience in individual development: Successful adaptation despite risk and adversity. In M. Wang, and E. Gordon, (Eds.). Educational resilience in inner-city america: Challenges and prospects. Hillsdale, NJ: Lawrence Erlbaum Associates ; 1994.

4. Ormrod JE. Educational psychology: Developing learners (5th ed.). Upper Saddle River, N.J.: Pearson/Merrill Prentice Hall ; 2006.

5. Golembiewski RT, Munzenrider RT. Phases of burnout: Developments in concepts and applications. New York: Praeger ; 1988.

6. Young-Eisendrath $P$. The resilient self: Transforming suffering into insight and renewal. New York: Addison-Wesley ; 1996.

7. Freudenberger $\mathrm{HJ}$. The staff burnout syndrome in alternative institutions. Psychotherapy: Theory, Research, and Practice 1975;12:73-82.

8. Gordon KA. Self-concepts and motivational patterns of resilient African American high school students. J Black Psychol 2002;21(3):239-255.

9. Golden L, Schmidt S, Shirley J. Unethical practice as perceived by mental health professionals: The next generation. Counseling Values 1998;42(3):166-170.

10. Heider F. The Psychology of Interpersonal Relations. New York: John Wiley \& Sons ; 1958.

11. Krovetz ML. Fostering resiliency: Expecting all students to use their minds and hearts well. Thousand Oaks, CA: Corwin Press ; 1999.

12. Locke EA, Latham GP. A theory of goal setting and task performance. Englewood Cliffs, NJ: Prentice Hall ; 1990.

13. Lifton RJ. The protean self: Human resilience in an age of transformation. New York: Basic Books ; 1993.

14. Reivich K, Shatte A. The resilience factor: Seven essential skills for overcoming life's inevitable obstacles. New York, NY: Broadway Books ; 2002.

15. Walsh F. Strengthening family resilience. New York: Gilford Press ; 1995.

Acknowledgements - Nil

Conflict of Interest - Nil

Funding - Nil. 